\title{
Pyrolysis of Spirulina platensis Residue: Effect of Temperature without and with Fe-oxide catalyst
}

\section{Pirolisis Spirulina platensis Residue: Pengaruh Suhu Tanpa dan Dengan Katalis Fe-oxide}

\author{
Siti Jamilatun a,1,*, Tyas Aji Kurniawan a,2, Adhi Chandra Purnama a,3, Irfan Maulana Putra ${ }^{a, 4}$ \\ a Program Studi Teknik Kimia, Universitas Ahmad Dahlan, Jl. Ringroad Selatan, Kragilan, Tamanan, Bantul, D. I. Yogyakarta, 55191, Indonesia \\ ${ }^{1}$ sitijamilatun@che.uad.ac.id*; ${ }^{2}$ sidiqfarhat@gmail.com; ${ }^{3}$ gusadhialhabsyi@gmail.com; ${ }^{4}$ irfan1700020157@webmail.uad.ac.id \\ * corresponding author
}

\section{ARTICLE INFO}

\section{Article history}

Received September 28, 2020

Revised January 10, 2021

Accepted January 31, 2021

Keywords

Bio-oil

Fe-oxide

Pyrolysis

Spirulina platensis residue

\section{ABSTRACT}

The limited fuel reserves must be addressed immediately. One of the biomass that has the potential for renewable energy is microalgae. The advantages of microalgae compared to other biomass is the oil produced, the speed of growth, and does not interfere with food availability. The processing of residual Spirulina platensis microalgae $(S P R)$ by pyrolysis is simple and does not cause pollution. This study's purpose was SPR pyrolysis with a grain size of 140 mesh without and with 5 wt.\% Fe-oxide catalyst. The variables studied were temperature on the yield of bio-oil products, water phase, charcoal, and gas. Pyrolysis was carried out in a fixed bed reactor at 300, 400, 500, 550, and $600{ }^{\circ} \mathrm{C}$. The higher the pyrolysis temperature, the higher the biooil yield, with the optimum catalyst at $400{ }^{\circ} \mathrm{C}$ produced $15.34 \%$ and without a catalyst at a temperature of $500{ }^{\circ} \mathrm{C}$ produced $15.00 \%$. The water yield phase in the range of $300-600{ }^{\circ} \mathrm{C}$ is higher for catalyst use (30\%-39\%) than without catalyst (13.75\%-22.25\%). The higher the pyrolysis temperature, the lower the yield char. The yield of gas without a catalyst was higher in the range of $30.69 \%-38.94 \%$ compared to catalyst $12.58 \%-26.18 \%$. At a temperature of $300{ }^{\circ} \mathrm{C}$ without a catalyst, the conversion obtained was $48.69 \%$, while with catalyst, $60.08 \%$.

This is an open access article under the CC-BY-SA license.

\section{Pendahuluan}

Saat ini kebutuhan minyak bumi dan BBM dalam negeri dipenuhi dari produksi minyak bumi dalam negeri, impor minyak bumi dan impor BBM. Meskipun minyak bumi dengan spesifikasi kilang telah diproses di kilang minyak dalam negeri, namun tidak bertambahnya kapasitas kilang selama 20 tahun terakhir dan konsumsi BBM yang terus meningkat menyebabkan impor BBM semakin besar dari tahun ke tahun. Dalam kurun waktu dari 2017-2050 diperkirakan impor minyak bumi akan meningkat 5 kali lipat, meningkat dari 181,9 juta barel pada tahun 2017 menjadi 924,9 juta barel pada tahun 2050 dengan pertumbuhan 5,1\% per tahun. Minyak bumi yang tidak dapat diproses di kilang akan diekspor dan jumlahnya terus menurun sampai tidak ada lagi ekspor pada tahun 2036. Bila ekspor ini dipertimbangkan maka net import minyak bumi dalam kurun waktu tersebut diperkirakan akan meningkat dari 79,2 juta barel pada tahun 2017 menjadi 924,9 juta barel pada tahun 2050 dengan tingkat pertumbuhan $7,7 \%$ per tahun [1].

Menipisnya cadangan minyak bumi berbasis fosil dan peningkatan impor BBM mendesak untuk ditanggulangi dengan menyediakan bahan bakar terbarukan yang aman bagi lingkungan [2,3]. Salah 
satu sumber energi terbarukan yang melimpah adalah biomassa, dan yang potensial untuk dikembangkan adalah biomassa generasi ketiga yakni mikroalga [4]. Mikroalga memiliki beberapa keuntungan dibandingkan sumber energi biomassa lainnya karena tingkat pertumbuhannya sangat tinggi (hingga $20 \mathrm{~g}$ ganggang kering per $\mathrm{m}^{2}$ per hari), hasil per area juga tinggi, yakni 10-23 kali lebih tinggi dari kelapa sawit. Selain itu, efisiensi yang tinggi dalam hal menangkap $\mathrm{CO}_{2}$ dan konversi energi surya, tidak berkompetisi dengan bahan pangan, tumbuh di perairan terbuka (air laut dan kolam) dan dalam photobioreaktor di lahan non-pertanian, dan tidak membutuhkan lahan yang luas untuk pertumbuhannya $[5,6,7]$.

Pengolahan biomassa mikroalga dengan pirolisis sangat menguntungkan, penggunaan teknologi sederhana, tidak membutuhkan bahan aditif yang berbahaya dan tidak menghasilkan limbah $[9,10]$. Produk pirolisis mikroalga berupa bio-oil, water phase, char dan gas [11]. Bio-oil dan gas dapat digunakan sebagai bahan bahar, water phase digunakan sebagai bahan aditif untuk pengawetan makanan dan mengandung komponen sebagai suplemen, sedangkan char dapat digunakan sebagai adsorben dalam bidang makanan, farmasi, pengolahan limbah dll. Produk pirolisis sangat bergantung pada beberapa parameter yaitu komposisi biomassa, heating rate, suhu pirolisis, waktu tinggal, ukuran butir biomassa, dan penggunaan katalis $[5,8,11]$.

Bio-oil hasil pirolisis masih mengandung senyawa oksigenat yang berpotensi menyebabkan korosi pada mesin. Oleh karena itu bio-oil masih membutuhkan perlakuan untuk mengurangi kandungan oksigenat, salah satu cara adalah pemakaian katalis dalam pirolisis [12,13]. Jamilatun et al., 2019 [14] telah menggunakan silika-alumina dalam pirolisis mikroalga Spirulina platensis residue (SPR), hasilnya adalah perbaikan kualitas bio-oil dengan pengurangan kandungan oksigenat dari $60,28 \%$ menjadi 32,15 wt.\%, atau terjadi penurunan senyawa oksigenat sekitar $46,67 \%$. Tambahan lagi, peningkatan nilai kalor rata-rata dari 16,66 MJ/kg menjadi 23,63 MJ/kg, meningkat sebesar $41,84 \%$. Disamping perbaikan kualitas bio-oil maka pirolisis katalitik ini menghasilkan syngas lebih banyak tetapi terjadi penurunan yield bio-oil dibanding pirolisis tanpa katalis [14,15].

Besi oksida dianggap sebagai bahan katalitik yang menjanjikan karena efisiensinya yang tinggi, ramah lingkungan, dan biaya rendah. $\alpha-\mathrm{Fe}_{2} \mathrm{O}_{3}$ (hematite) adalah salah satu polimorf oksida besi yang paling stabil dalam kondisi ambien dan digunakan dalam berbagai bidang katalisis, terutama dalam reaksi reduksi/oksidasi dan asam/basa. $\mathrm{Fe}_{2} \mathrm{O}_{3}$ berguna untuk oksidasi $\mathrm{CO}$, oksidasi air fotokatalitik, reduksi $\mathrm{NO}_{x}$ menjadi $\mathrm{NH}_{3}$ pada knalpot diesel [16].

Penelitian ini bertujuan untuk mengetahui pengaruh suhu pada pirolisis tanpa dan dengan penambahan katalis Fe-Oksida 5 wt.\% terhadap yield produk (bio-oil, water phase, char, dan gas) dan konversi. Bahan baku berupa SPR dengan ukuran butir 140 mesh terlebih dahulu dianalisis proksimat dan ultimat sebelum digunakan. Penelitian ini dijalankan dengan heating rate dijaga konstan yakni pada kisaran $8-15{ }^{\circ} \mathrm{C} /$ menit. Pirolisis dilakukan dengan fixed-bed reactor yang terdiri dari dua silinder yang disusun seri secara vertical, silnder pertama untuk SPR, silinder kedua untuk katalis Fe-oxide. Produk pirolisis berupa bio-oil, water phase, char dan gas. Dari penelitian ini akan didapatkan kondisi optimum tanpa dan dengan pemakaian katalis.

\section{Metode Penelitian}

\subsection{Bahan dan Alat}

1) Spirulina platensis Residue (SPR)

SPR kering dengan ukuran 140 mesh diperoleh dari residu padat ekstraksi Spirulina platensis (SP) segar. Sampel SPR dan SP dianalisis ultimat dan proksimat dan nilai HHV-nya. Analisis proksimat dilakukan di Laboratorium Pangan dan Hasil Pertanian, Departemen Teknologi Pertanian dan Lab Pangan dan Gizi dari Pusat Antar Universitas (PAU) UGM [2,14]. Adapun analisis ultimat di Laboratorium Analisis dan Pengujian, Puslitbang Tekmira Bandung.

Hasil analisis proksimat dan ultimat SPR dan SP mempunyai komposisi yang hampir sama, seperti ash (8,63-8,69 wt.\%), volatile (67,03-68,31 wt.\%) dan fixed carbon (12,51-12,77wt.\%). Dari hasil analisis ultimate untuk komponen C (41,36-41,91 wt.\%), H (6,60-6,82 wt.\%), dan N (7,17-8,89 wt.\%), kecuali pada O mengalami sedikit kenaikan dengan SP sebanyak 33,04 wt.\% dan pada SPR 35,33 wt.\%. Sedangkan untuk analisis proksimat terlihat lipid pada SP $(0,25 w t . \%)$ dan SPR $(0,09 w t . \%)$ sangat rendah [11]. Berdasarkan perbandingan hasil analisis sebelum dan sesudah 
ekstraksi adalah bahan tidak mengalami perubahan komposisi yang berarti, hal ini karena kandungan lipid pada SP sangat rendah maka pengaruh ekstraksi tidak begitu terlihat.

2) Fe-oxide

Katalis yang digunakan yaitu $\mathrm{Fe}$-oxide yang diperoleh dari PT Pupuk Kujang Cikampek Jawa Barat dalam bentuk pellet berwarna coklat kehitaman. Fe-oxide powder ukuran partikel kurang dari $50 \mathrm{~nm}$ (nanopowder), surface area 50-245 m²/g. Berdasarkan hasil analisis $\mathrm{Fe}$-oxide dengan SEM, diperoleh hasil komposisi $\mathrm{C}, \mathrm{O}, \mathrm{Cr}, \mathrm{Fe}$, dan $\mathrm{Cu}$ masing-masing adalah 8,04; 28,75; 4,93; 56,64 dan 1,64 wt. $\%$.

\section{3) Alat Penelitian}

Percobaan proses pirolisis mikroalga SPR dengan penambahan katalis $\mathrm{Fe}$-oxide menggunakan fixed-bed reactor yang terbuat dari stainless steel memiliki dimensi: diameter dalam $40 \mathrm{~mm}$, diameter luar $44 \mathrm{~mm}$ dan tinggi $60 \mathrm{~mm}$. Reaktor dilengkapi dengan pemanas. Diagram alat untuk sistem fixed-bed reactor disajikan pada Gambar 1. Reaktor dipanaskan secara eksternal oleh tanur listrik, lalu suhu dikendalikan secara manual dengan mengatur voltase pada voltmeter yang terhubung dengan thermocouple NiCr-Ni yang ditempatkan di luar tungku. Kondensor digunakan untuk mengembunkan gas hasil pirolisis sebelum ditampung pada penampung $[5,11,14,17]$.

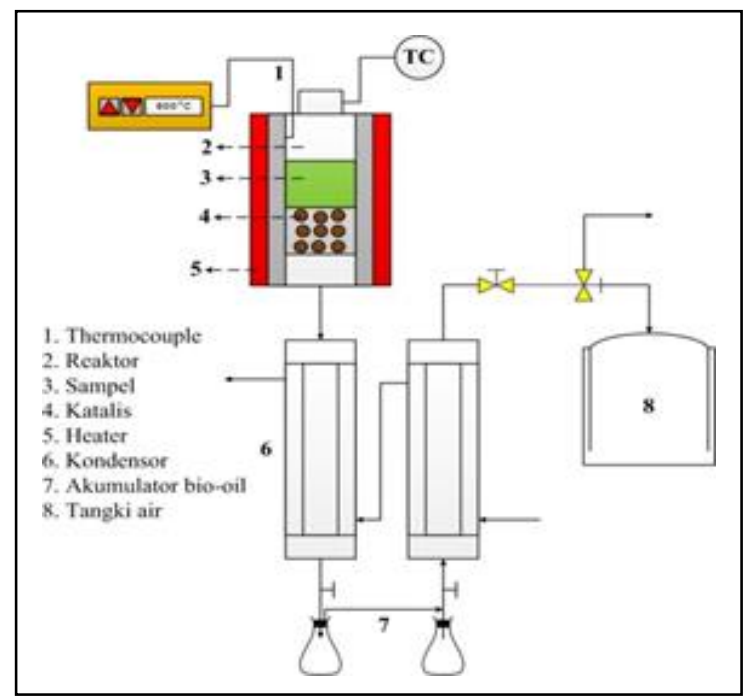

Gambar 1. Rangkaian Alat Percobaan

\subsection{Prosedur Penelitian}

Lima puluh (50) gram SPR dimasukkan dalam silider satu bagian atas, kemudian katalis $\mathrm{Fe}$ oxide 5 wt.\% dimasukkan dalam silinder dua pada fixed-bed reactor sesuai susunan. Setelah itu ditutup rapat dan dipanaskan. Sampel yang diuji dipanaskan dengan tingkat pemanasan konstan dari suhu kamar sampai ke suhu yang diinginkan $\left(300,400,500,550,600^{\circ} \mathrm{C}\right)$. Untuk mengetahui suhu sudah tercapai digunakan thermocouple yang dimasukkan dari atas lubang reaktor. Produk cair keluar kondensor dikumpulkan dalam akumulator, produk gas dijerap dengan air pada gallon air dan char diambil sesudah proses selesai. Bio-oil dan water phase dapat diukur beratnya, char ditimbang dan gas dihitung dari selisih berat awal dikurangi berat cairan dan char. Yield produk meliputi biooil, water phase, tar, char, dan gas. Yield produk beserta konversi pirolisis dihitung dengan persamaan 1-7 [17].

Total produk cair, berat bio-oil dan berat gas dihitung dengan persamaan $[2,17]$ :

$$
\begin{aligned}
Y_{L} & =\left[\frac{W_{L}}{W_{M}}\right] x 100 \% \\
Y_{B} & =\left[\frac{W_{B}}{W_{M}}\right] x 100 \% \\
Y_{A} & =\left[\frac{W_{A}}{W_{M}}\right] x 100 \%
\end{aligned}
$$




$$
\begin{aligned}
& Y_{C}=\left[\frac{W_{C}}{W_{M}}\right] x 100 \% \\
& Y_{G}=1-\left[Y_{L}-Y_{C}\right] \\
& W_{L}=\left[W_{B}+W_{A}\right] \\
& X=\left[\frac{W_{B}+W_{A}+W_{G}}{W_{M}}\right] \times 100 \%
\end{aligned}
$$

Dalam hal ini, $\mathrm{Y}_{\mathrm{L}}$ adalah yield hasil produk cair atau tar; $\mathrm{W}_{\mathrm{L}}$ adalah berat dari produk cair atau tar; $\mathrm{W}_{\mathrm{M}}$ adalah berat $\mathrm{SPR} ; \mathrm{Y}_{\mathrm{A}}$ adalah yield produk water phase; $\mathrm{W}_{\mathrm{A}}$ adalah berat produk water phase; $\mathrm{Y}_{\mathrm{B}}$ adalah yield bio-oil; $\mathrm{W}_{\mathrm{B}}$ adalah berat bio-oil; $\mathrm{Y}_{\mathrm{C}}$ adalah yield char; $\mathrm{W}_{\mathrm{C}}$ adalah berat char dan $\mathrm{Y}_{\mathrm{G}}$ adalah yield gas produk. $\mathrm{X}$ adalah konversi pirolisis.

\section{Hasil dan Pembahasan}

\subsection{Yield Bio-oil}

Pengaruh suhu tanpa katalis dan pemakaian katalis Fe-oxide 5 wt.\% terhadap yield bio-oil pada pirolisis SPR dengan ukuran butiran 140 mesh disajikan pada Gambar 2, perhitungan yield bio-oil menggunakan Persamaan 1.

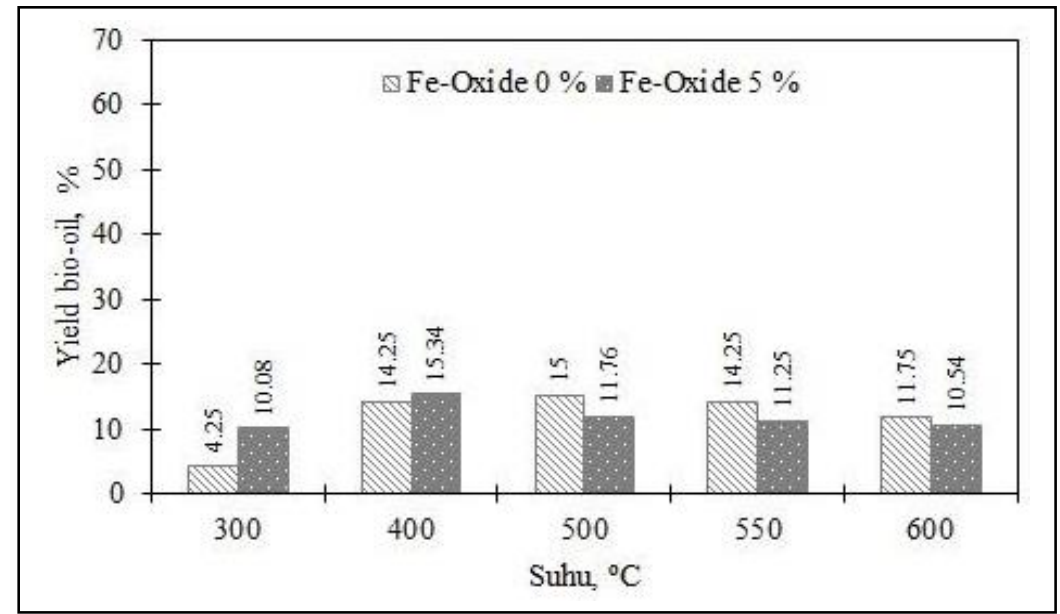

Gambar 2. Pengaruh suhu terhadap yield bio-oil tanpa dan dengan Fe-oxide 5 wt.\%

Berdasarkan Gambar 2, dapat dilihat pengaruh suhu terhadap yield bio oil pada pirolisis SPR dengan katalis pada suhu $300{ }^{\circ} \mathrm{C}$ diperoleh yield sebesar 10,08\%, sedangkan tanpa katalis diperoleh $4,25 \%$. Yield maksimum dengan katalis diperoleh pada $400{ }^{\circ} \mathrm{C}$ sebesar $15,34 \%$, sesudah itu turun sampai $10,54 \%$ pada $600{ }^{\circ} \mathrm{C}$. Adapun tanpa katalis diperoleh suhu optimum pada $500{ }^{\circ} \mathrm{C}$ yakni $15,00 \%$, sesudah itu turun sampai $11,75 \%$ pada $600{ }^{\circ} \mathrm{C}$. Kondisi ini dapat diartikan bahwa proses perengkahan atau cracking dengan katalis paling aktif terjadi pada suhu $400{ }^{\circ} \mathrm{C}$, terjadi pemutusan ikatan C-C dari rantai karbon panjang (polimer) dengan berat molekul besar menjadi rantai karbon pendek (monomer) dengan berat molekul yang kecil. Meningkatnya suhu menyebabkan proses perengkahan semakin baik, rantai hidrokarbon yang terputus ikatannya juga semakin banyak sehingga menyebabkan yield semakin tinggi [13]. Perengkahan tanpa katalis paling aktif terjadi pada $500{ }^{\circ} \mathrm{C}$, dicapai lebih tinggi daripada dengan katalis $400{ }^{\circ} \mathrm{C}$. Pada pemakaian katalis mulai $500{ }^{\circ} \mathrm{C}$ jumlah bio-oil semakin menurun, hal ini disebabkan terjadinya secondary cracking dimana tar yang dihasilkan dari primary cracking akan terdekomposisi menjadi gas dan char [18]. Dekomposisi lanjutan ini akan menyebabkan yield gas semakin naik, sebaliknya yield bio-oil menurun [2]. Penambahan pembentukan char pada secondary cracking sangat kecil sehingga tidak berpengaruh terhadap pembentukan char [19].

\subsection{Yield water phase}

Pengaruh suhu tanpa dan dengan katalis Fe-oxide 5 wt.\% terhadap pembentukan water phase dengan ukuran butiran SPR 140 mesh disajikan pada Gambar 3, perhitungan menggunakan 
Persamaan 2. Gambar tersebut menjelaskan pengaruh suhu terhadap yield water phase, pada suhu $300{ }^{\circ} \mathrm{C}$ dengan katalis yield water phase yang diperoleh sebesar $30 \%$. Pada suhu $400{ }^{\circ} \mathrm{C}$ naik menjadi $39 \%$, selanjutnya pada suhu 500,550 , dan $600{ }^{\circ} \mathrm{C}$ yield water phase turun naik kemudian turun kembali, yakni 35\%, 39\%, dan 35\%. Secara keseluruhan kisaran suhu yield water phase pada kisaran 30-39\%. Pada suhu optimum $400{ }^{\circ} \mathrm{C}$ saat menghasilkan yield bio-oil maksimum, diperoleh yield water phase cukup tinggi sebesar $39 \%$. Yield water phase pada kisaran $300-600{ }^{\circ} \mathrm{C}$ tanpa katalis secara keseluruhan lebih rendah $(13,75 \%-22,25 \%)$ jika dibandingkan dengan pemakaian katalis 5 wt.\% (30,00\%-39,00\%). Fenomena ini disebabkan terjadinya reaksi hidrogenasi dan hidrodeoksigenasi yang lebih aktif sehingga pembentukan air lebih banyak [14,20].

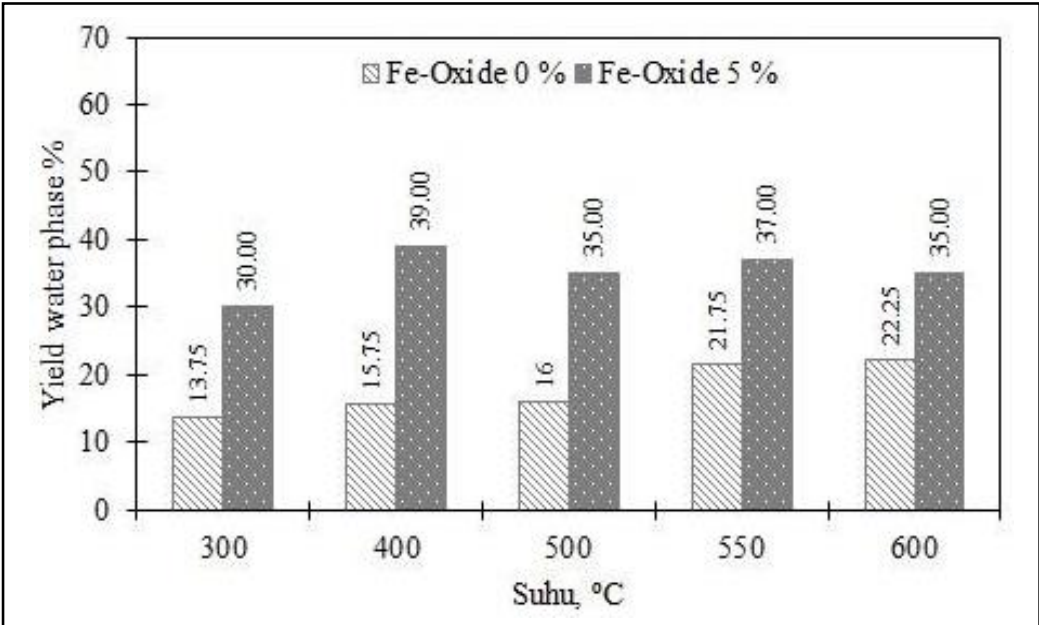

Gambar 3. Pengaruh suhu terhadap yield water phase tanpa dan dengan $\mathrm{Fe}$-oxide 5 wt.\%

\subsection{Yield Tar}

Tar adalah campuran produk bio-oil dan water phase atau disebut juga produk cair. Pengaruh suhu tanpa dan dengan pemakaian Fe-oxide 5 wt.\% hasilnya dapat dilihat pada Gambar 4, perhitungan mengikuti Persamaan 6.

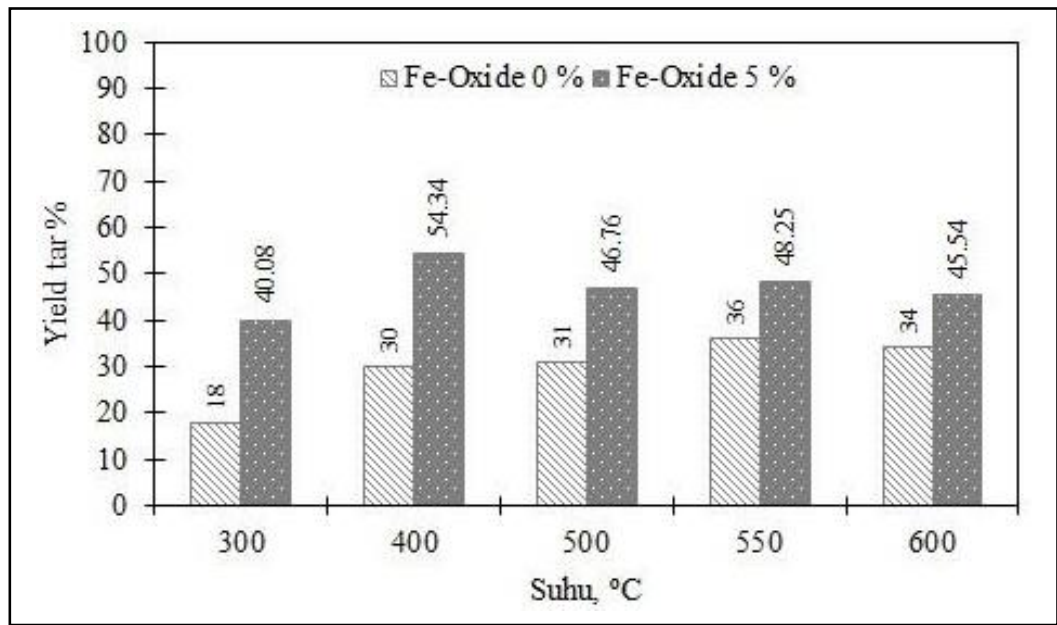

Gambar 4. Pengaruh suhu terhadap yield tar tanpa dan dengan $\mathrm{Fe}$-oxide $5 \mathrm{wt} . \%$

Berdasarkan gambar tersebut dapat dilihat bahwa pada pirolisis $300-600{ }^{\circ} \mathrm{C}$ jumlah tar dengan katalis lebih tinggi dibandingkan tanpa katalis. Pengaruh katalis dalam mengaktifkan reaksi hidrogenasi dan hidrodeoksigenasi lebih dominan daripada pengaruh kandungan air dalam SPR. Kondisi optimum tar pada pemakaian katalis diperoleh pada suhu $400{ }^{\circ} \mathrm{C}$ yakni $54,34 \%$, sedangkan tanpa katalis diperoleh pada $550{ }^{\circ} \mathrm{C}$ yakni $36 \%$.

\subsection{Yield Char}

Pengaruh suhu terhadap yield char tanpa dan dengan katalis ditampilkan pada Gambar 5, perhitungan mengikuti Persamaan 4. Berdasarkan gambar tersebut untuk pirolisis dengan dan tanpa 
katalis dapat dilihat semakin tinggi suhu pirolisis semakin turun yield char. Pada suhu 300, 400, 500,550 , dan $600{ }^{\circ} \mathrm{C}$ persentase yield char masing-masing sebesar 39,92; 33,08; 30,24; 28,32 dan 28,20 . Pirolisis pada suhu rendah kurang dari $400{ }^{\circ} \mathrm{C}$ atau pemanasan rendah relatif menghasilkan tingkat char yang lebih tinggi. Semakin tinggi suhu pirolisis maka dekomposisi semakin meningkat sehingga produk cairan dan gas semakin banyak, hal ini menyebabkan yield char semakin turun. Heating rate tinggi dan waktu tinggal yang lebih lama juga menyebabkan reaksi secondary cracking lebih aktif, maka yield char semakin turun [20,21,22]. Pada pirolisis tanpa katalis suhu $300{ }^{\circ} \mathrm{C}$ diperoleh yield char jauh lebih tinggi yakni 51,31\% dibanding dengan katalis 39,92\%. Untuk suhu 400-600 ${ }^{\circ} \mathrm{C}$ dengan dan tanpa katalis pengaruhnya tidak signifikan terhadap yield char.

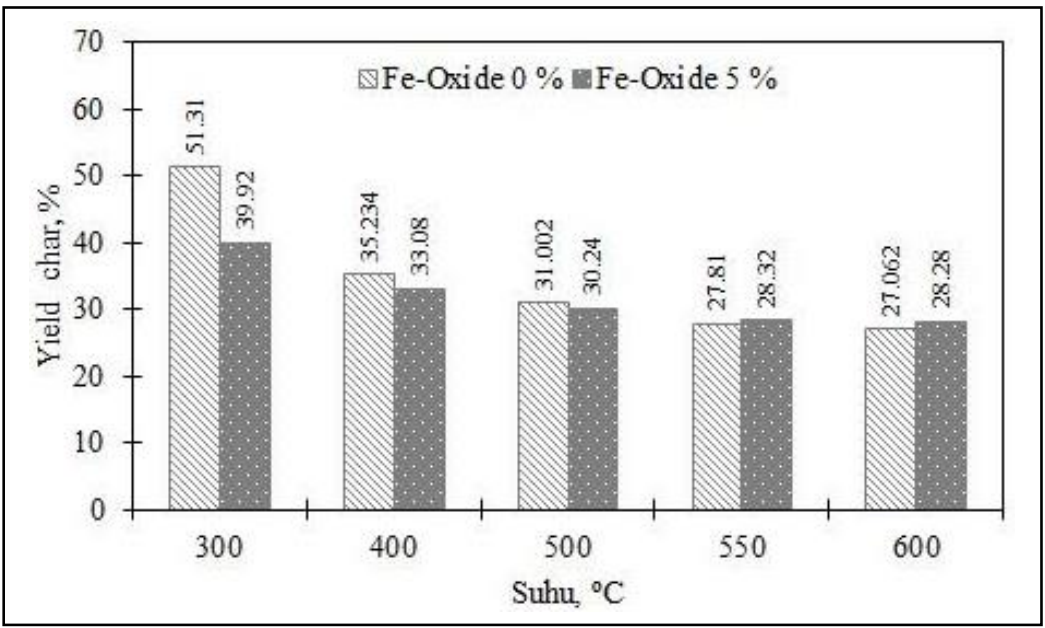

Gambar 5. Pengaruh suhu terhadap yield char tanpa dan dengan $\mathrm{Fe}$-oxide 5 wt.\%.

\subsection{Yield Gas}

Pengaruh suhu terhadap yield gas tanpa dan dengan katalis $\mathrm{Fe}$-oxide 5 wt.\% disajikan pada Gambar 6, perhitungan mengikuti Persamaan 5. Berdasarkan gambar tersebut dapat dilihat bahwa dengan katalis yield gas pada suhu $300{ }^{\circ} \mathrm{C}$ sebesar $20,00 \%$, menurun pada suhu $40{ }^{\circ} \mathrm{C}(13 \%)$. Selanjutnya persentase yield gas akan naik pada suhu 500,550 , dan $600{ }^{\circ} \mathrm{C}$, berturut-turut adalah 23,$00 ; 23,43$ dan $26,18 \%$. Semakin tinggi suhu pirolisis maka yield gas semakin besar, sebaliknya pada $400{ }^{\circ} \mathrm{C}$ terjadi penurunan yang cukup drastis. Hal ini disebabkan pada suhu $400{ }^{\circ} \mathrm{C}$ yield water phase sangat tinggi, yakni 39\% yang disebabkan karena reaksi hidrodeoksigenasi dan hidrogenasi. Pada suhu lebih besar dari $600{ }^{\circ} \mathrm{C}$ pirolisis menghasilkan lebih banyak produk gas yang menyebabkan yield bio-oil rendah. Hal ini disebabkan adanya proses perengkahan dari mikroalga yang berhubungan dengan secondary cracking, apabila suhu semakin tinggi maka perengkahan akan meningkat [22]. Perbandingan yield gas pirolisis $300-600{ }^{\circ} \mathrm{C}$ tanpa dan dengan katalis adalah tanpa katalis lebih tinggi pada kisaran 30,69\%-38,94\% dibandingkan dengan Fe-oxide 12,58\%-26,18\%.

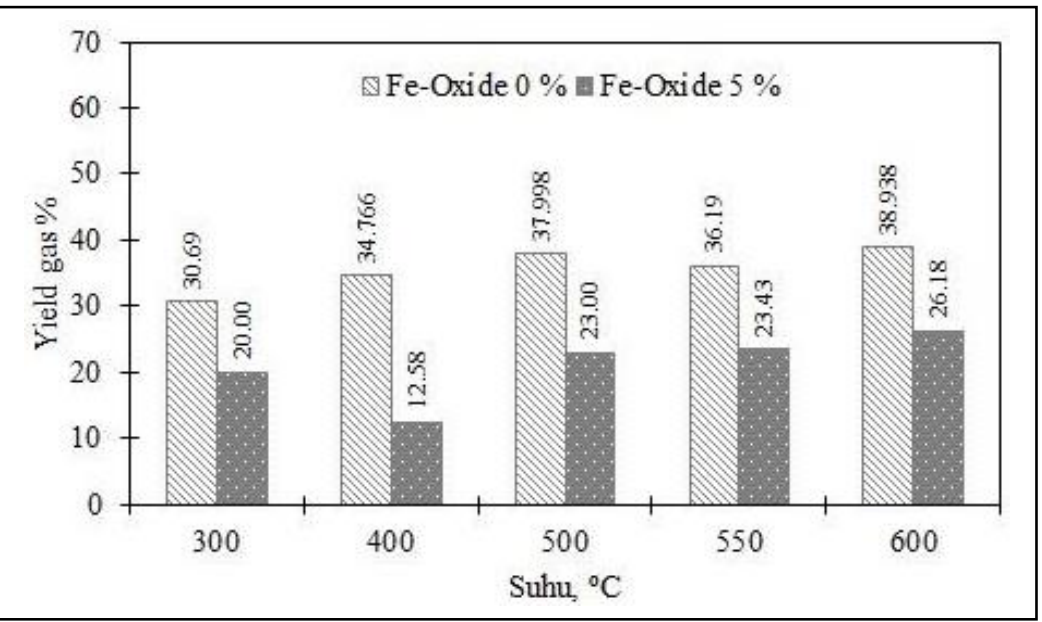

Gambar 6. Pengaruh suhu terhadap yield gas tanpa dan dengan $\mathrm{Fe}$-oxide 5 wt.\% 


\subsection{Konversi}

Pirolisis tanpa dan dengan katalis mempunyai kecenderungan yang sama yakni semakin tinggi suhu konversi semakin meningkat, dapat dilihat pada Gambar 7. Perhitungan konversi mengikuti Persamaan 7. Pengaruh pemakaian $\mathrm{Fe}$-oxide terlihat signifikan pada suhu $300{ }^{\circ} \mathrm{C}$, tanpa dan dengan katalis masing-masing adalah $48,69 \%$ dan $60,08 \%$. Pada suhu $500-600{ }^{\circ} \mathrm{C}$ pengaruh suhu dan $\mathrm{Fe}$ oxide tidak signifikan pengaruhnya terhadap konversi. Pada suhu diatas $500{ }^{\circ} \mathrm{C}$ pengaruh katalis cenderung mengaktifkan terjadinya reaksi deoksigenasi, yakni pengurangan senyawa oksigenat pada condensable gas (bio-oil) [14].

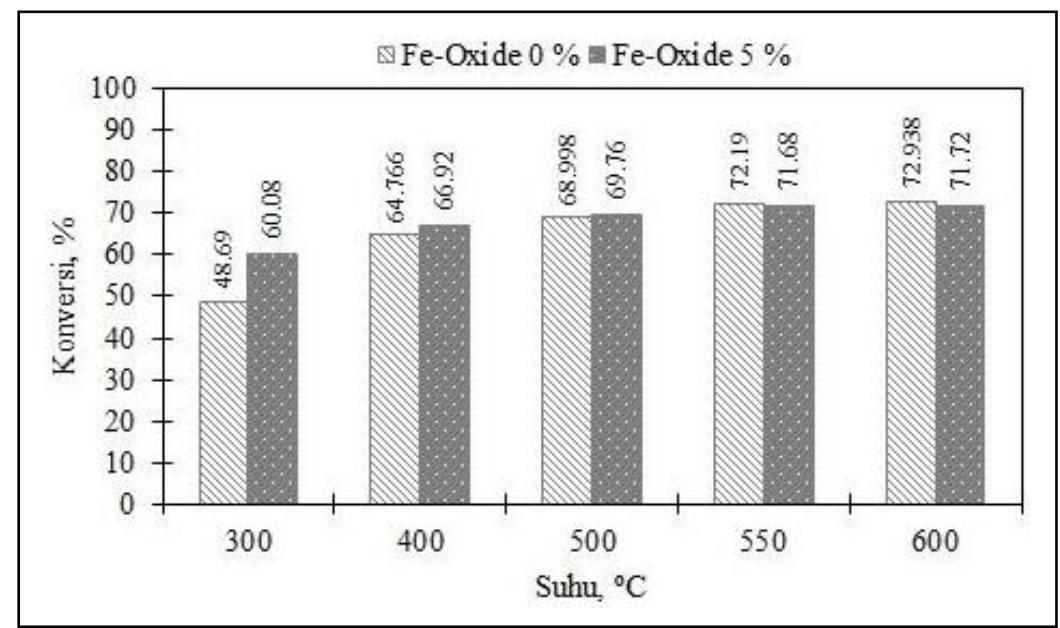

Gambar 7. Pengaruh suhu terhadap konversi pada pemakaian $\mathrm{Fe}$-oxide 5\%

\section{Kesimpulan}

Pirolisis Spirulina platensis residue dengan ukuran butir 140 mesh tanpa dan dengan pemakaian Fe-oxide 5 wt.\% dilakukan pada fixed-bed reactor, dengan heating rate $8-15{ }^{\circ} \mathrm{C} / \mathrm{menit}$ dari suhu $300-600{ }^{\circ} \mathrm{C}$. Semakin tinggi suhu pirolisis semakin naik yield bio-oil, optimum pada $400{ }^{\circ} \mathrm{C}$ untuk pemakaian $\mathrm{Fe}$-oxide 5 wt.\% yakni $15,34 \%$. sesudah itu turun sampai $10,54 \%$ pada $600{ }^{\circ} \mathrm{C}$. Pirolisis tanpa katalis diperoleh suhu optimum pada $500{ }^{\circ} \mathrm{C}$ yakni $15,00 \%$, sesudah itu turun sampai $11,75 \%$ pada $600{ }^{\circ} \mathrm{C}$. Yield water phase pada kisaran $300-600{ }^{\circ} \mathrm{C}$ lebih tinggi untuk pemakaian $\mathrm{Fe}$-oxide (30$39 \%$ ) dibandingkan tanpa katalis $(13,75-22,25 \%)$. Kondisi optimum tar pada pemakaian katalis diperoleh pada suhu $400{ }^{\circ} \mathrm{C}$ yakni $54,34 \%$, sedangkan tanpa katalis diperoleh pada $550{ }^{\circ} \mathrm{C}$ yakni $36 \%$. Semakin tinggi suhu pirolisis semakin turun yield char. Pada pirolisis tanpa katalis suhu 300 ${ }^{\circ} \mathrm{C}$ diperoleh yield char jauh lebih tinggi yakni $51,31 \%$ dibanding dengan katalis $39,92 \%$. Yield gas pada 300-600 ${ }^{\circ} \mathrm{C}$ tanpa katalis lebih tinggi pada kisaran 30,69\%-38,94\% dibandingkan dengan $\mathrm{Fe}$ oxide 12,58\%-26,18\%. Pengaruh pemakaian $\mathrm{Fe}$-oxide terlihat signifikan pada suhu $300{ }^{\circ} \mathrm{C}$, tanpa katalis diperoleh konversi $48,69 \%$, sedangkan dengan katalis $60,08 \%$. Pada suhu $500-600{ }^{\circ} \mathrm{C}$ pengaruh suhu dan $\mathrm{Fe}$-oxide tidak signifikan pengaruhnya terhadap konversi.

\section{Ucapan Terima Kasih}

Penulis mengucapkan terima kasih atas bantuan dana penelitian melalui Skema Dana Penelitian Internal melalui Lembaga Penelitian dan Pengabdian Masyarakat Universitas Ahmad Dahlan Yogyakarta dengan nomor kontrak: PD-237/SP3/LPPM-UAD/2020.

\section{Daftar Pustaka}

[1] Badan pengkajian dan Penerapan Teknologi-Outlook Energi Indonesia 2019. (BPPT-OEI, 2019).

[2] S. Jamilatun, Budhijanto, Rochmadi, and A. Budiman, "Thermal Decomposition and Kinetic Studies of Pyrolysis of Secondary cracking. International Journal of Renewable Energy Development, 6(3), 193201, 2017.

[3] S. Jamilatun, D. Kusuma, ASS. Shakti dan F. Ferdiant, "Pembuatan Biocoal Sebagai Bahan Bakar Alternatif dari Batubara dengan Campuran Arang Serbuk Gergaji Kayu Jati, Glugu dan Sekam Padi", Prosiding Seminar Nasional Teknik Kimia "Kejuangan", Pengembangan Teknologi Kimia untuk PengolahanSumber Daya Alam Indonesia, ISSN 1693 - 4393, 2010. 
[4] C. Kilic, Gokhan, SAkl. and Gokpinar, S., "Comparing to The Vomit of In Two Different Spirulina platensis Growth Features", Fish Aquat. Sci., 23, 189-192. 2006.

[5] S. Jamilatun, Budhijanto, Rochmadi, A. Yuliestyan, H. Hadiyanto, and A. Budiman, "Comparative analysis between pyrolysis products of Spirulina platensis biomass and its residues", Int. J. Renew. Energy Dev., vol. 8, no. 2, pp. 133-140, 2019.

[6] A. Campanella, R. Muncrief, M.P. Harold, D.C. Griffith, N.M. Whitton, and R.S. Weber, "Thermolysis of microalgae and duckweed in a CO2- wept fixed-bed reactor: Bio-oil yield and compositional effects". Bioresource Technology, 109, 154-162, 2012.

[7] S.O. Gultom, C. Zamalloa, and B. Hu, "Microalgae Harvest through Fungal PalletizationCo-Culture of Chlorella Vulgaris and Aspergillus niger". Journal Energies. 7(7):4417-442, 2014.

[8] S. Jamilatun, Budhijanto, Rochmadi, A. Yuliestyan, and A. Budiman, "Valuable Chemicals Derived from Pyrolysis Liquid Products of Secondary cracking", Indones. J. Chem., 19 (3), 703 - 711, 2019.

[9] Z. Du, "Thermochemical Conversion of Microalgae for Biofuel Production", Disertasi. University of Minnesota: Minnesota, 2013.

[10]X. Miao, Q. Wu, and C. Yang, "Fast pyrolysis of microalgae to produce renewable Fuels", J. Anal. Appl. Pyrol., 71, 855-863, 2004.

[11]S. Jamilatun, Budhijanto, Rochmadi, A. Yuliestyan, and A. Budiman, "Effect of grain size, temperature and catalyst amount on pyrolysis products of Spirulina Platensis Residue (SPR)", International Journal of Technology 10(3), 541-550, 2019

[12]L. Chen, and K. Yoshikawa, "Bio-oil upgrading by cracking in two-stage heated reactors". AIMS Energy, 6(1): 203-215, 2018.

[13]D. Houshmand, B. Roozbehani, and A. Badakhshan, "Thermal and Catalytic Degradation of Polystyrene with a Novel Catalyst". Journal Emerging Technologies, 5(1), 234 -238, 2016.

[14]S. Jamilatun, A. Budiman, H. Anggorowati, A. Yuliestyan, Y. Surya Pradana, Budhijanto, and Rochmadi, "Ex-Situ Catalytic Upgrading of Secondary cracking oil using silica-alumina catalyst", Int. J. Renew. Energy Res. Vol. 9, No. 4, pp. 1733-1740.

[15]U. Jena, and K.C. Das, "Comparative Evaluation of Thermochemical Liquefaction and Pyrolysis for Bio-Oil Production from Microalgae", Energy \& Fuels, 25, 5472-5482, 2011.

[16] A. Baimoldina, K. Papadakis, and E.Y. Konysheva, "Diverse impact of $\alpha$-Fe2O3 with nano/micro-sized shapes on the catalytic fast pyrolysis of pinewood: Py-GC/MS study", Analytical and Applied Pyrolysis, $139,145-155,2019$.

[17]S. Jamilatun dan S. Salamah, "Pemanfaatan Asap Cair Food Grade yang Dimurnikan dengan Arang Aktif sebagai Pengawet Ikan Nila", Eksergi, 14 (2), 29-34, 2017.

[18]P.S. Rezaei, H. Shafaghat, W. Daud, "Production of green aromatic and olefins by catalytic cracking oxygenated compounds derived from biomass pyrolysis", Appl.Catal. A: Gen., 490(5) 11, 2011.

[19] P. Pan, C.W. Hu, W.Y. Yang, Y.S. Li, L.L. Dong, L.F. Zhu, D.M. Tong, R.W. Qing, and Y. Fan, "The direct pyrolysis and catalytic pyrolysis of Nannochloropsis sp residue for renewable bio-oils", Bioresource Technology, 101, 4593-4599, 2011.

[20] T. Dickerson, and J. Soria, “Catalytic fast pyrolysis: A Review”, Energy, 6, 514-538, 2013.

[21] Y. Yuan, T. Wang, and Q. Li, "Production of lowcarbon light olefins from catalytic cracking of crude bio-oil”, Chin. J. Chem. Phys., 26920, 237 - 244, 2013.

[22]D.R. Vardon, B.K. Sharma, G.V. Blazina, K. Rajagopalan, T.J. Strathmann, "Thermochemical conversion of raw and defatted algal biomass via hydrothermal liquefaction and slow pyrolysis", Bioresource Technology, 109, 178-87, 2012. 